\title{
男性糖尿病患者の性機能調査
}

\author{
札幌医科大学泌尿器科学教室 \\ 山口 康宏熊本 悦明
}

\section{STUDY OF SEXUAL FUNCTION OF MALE DIABETICS}

\author{
Yasuhiro Yamaguchi and Yoshiaki Kumamoto \\ Department of Urology, Sapporo Medical University \\ (Director: Prof. Yoshiaki Kumamoto)
}

We studied the actual general state of sexual dysfunction in 201 male diabetics (age range: $22 \sim 76$ years) who were commuting outpatients, using the Sapporo Medical University's Sexual Function Questionnaire. The control group consisted of 6,426 healthy male subjects. The principal parameters taken into account by the Questionnaire were the libido and ability to achieve/ maintain an erection, with consideration given to the factor of the subject's age.

The results were as follows.

1. The diabetic patients who were experiencing neuropathy showed a decrease in the ability to achieve/maintain an erection at an earlier age than the patients without neuropathy. In addition, the number of patients with a decreased ability to achieve/maintain an erection was found to be $30(45 \%)$ of 67 cases with neuropathy compared with 24 (18\%) of 134 cases without neuropathy. The severity of that decreased ability was also greater in the cases with neuropathy.

2. In comparison with the healthy male control subjects, the diabetics showed decreases in libido and the ability to achieve/maintain an erection which were not very severe at younger ages, but became striking after the age of about 60 years. Thus, the degree of dysfunction accelerated with increasing age. After the age of 60 years, the erection score was found to decrease in $31.7 \%$ of the patients without neuropathy but in $61.1 \%$ of the patients with neuropathy.

3. Weighted regression analysis showed that the most important factor involved in the ability to achieve/maintain an erection was the subject's age (contribution rate: $27.2 \%$ ), followed by neuropathy $(7.4 \%)$. These two factors represented the explanatory factor of erectile dysfunction in approximately $1 / 3$ of the diabetics. In addition, the factor of age accelerates the progress of damage to the blood vessels, and it is surmised that this deterioration is deeply involved in sexual dysfunction.

Key words: diabetes, sexual function, aging

\footnotetext{
要旨：糖尿病における性機能障害の一般的な実態を調査するため, 外来通院可能な男性糖尿病患者201例 （22〜76歳）に対して札幌医大式性機能質問紙を施行した。対照として健康男性6,426例を用い，おもに 性欲，勃起について年齢の因子を考慮しながら検討し，以下の結果を得た.

1. ニューロパチーのあるものはないものに比べ早期に勃起能が低下していた．また勃起能低下例は ニューロパチーのないもの134例中 24 例 (18\%) に対してニューロパチーのあるものが67例中 30 例 (45\%) と, 低下の頻度も高かった.

2. 性欲, 勃起とも, 糖尿病症例では健康男性に比し, 若年群でさほど低下せず, 60歳を過ぎるころよ り低下が著しくなり，加齢により障害が加速されていた．60歳以降に勃起得点の低下を示したものは,
} 


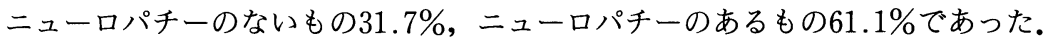

3. 重回㷌分析では，勃起に寄与する因子として第一に加齢（寄与率 $27.2 \%$ ), 続いてニューロパチー （寄与率 $7.4 \%$ ）が挙げられ，この 2 つ因子が糖尿病の勃起障害の説明因子として約 $1 / 3 を$ 占めていた. また加齢因子は血管障害をより加速することで性機能障害と強く結び付くことが推測された.

キーワード：糖尿病，性機能，加齢

\section{緒 言}

近年，糖尿病の治療学が進歩するにあたって，その 合併症への対策も重大な関心事となっている.しかし, その合併症のなかでもかなり高頻度に発生するといわ れる男性性機能障害"1にりいては，その病因について はいうまでもなく, 発生頻度についても未だ不明な点 が多い. 糖尿病の場合, 性機能が軽度から高度まで段 階的に低下していくことも多く，軽度の性機能障害で は羞恥心のためなかなか患者は主治医に訴え出ること は少ない．また高度性機能障害例に至っては直接泌尿 器科医を受診するため, 内科および泌尿器科の両サイ ドの医師にとって糖尿病の性機能障害の実態を全体と して掴みきれないこともその一因であろう。そこで 我々は，医師が直接性機能について問診しなくても， 患者が回答することで性機能の状態が点数で判断でき るような質問紙を作製してきた．まず多数例の健康成 人男性の性機能を調査し，加齢を考慮した男性性機能 の正常值の設定をおこなった ${ }^{21}$.これらの成績を踏ま え, 今回男性糖尿病201例にこの質問紙を施行し性機能 障害の実態を調査したので報告する。

\section{対象および方法}

外来通院可能な男性糖尿病患者201例 (22～76歳)に 対して自記式性機能質問紙を施行した. 加齢の影響を 考慮するため, 若年群 (45歳未満), 中年群 (45〜 59歳), 高齢群（60歳以上）の 3 群に分け解析をおこなった. このうち 67 例は合併症として四肢のニューロパチー （膝蓋，アキレス腱反射の消失や腓腹筋痛など）を有し ており，これは内科主治医の診断によった。

対照として健康成人男性 6,426 例にも同質問紙を記 入させ, 糖尿病と比較検討した。以下述べる性機能質 問紙の詳細については当教室の熊本 ${ }^{2)}$ の報告を参照さ れたい.

1）性機能質問紙について

質問紙は主に以下の項目より構成されている（図 $1)$.

(1) 性交頻度

(2) 性欲：視覚による性欲，接触による性欲

(3) 勃起 : 陰茎硬度, 勃起持続時間, 早期勃起

\section{図 1 札幌医大式性機能質問紙の質問項目と得点}

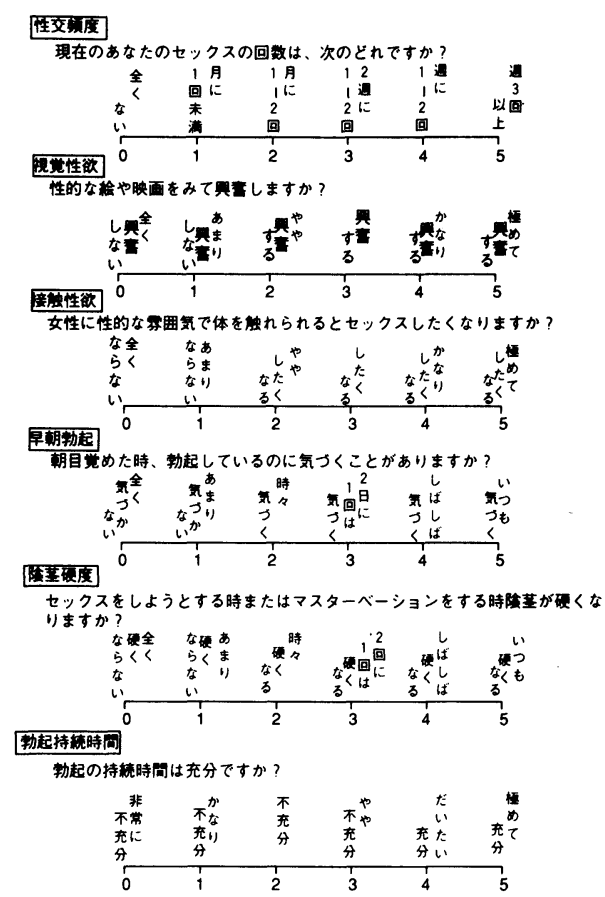

回答は自記式とし, 被験者自身が自己の状態像につ いて，それぞれの質問毎に $0 \sim 5$ 点までの間で, 該当 すると思う点数に○印を記入させるという方法をとっ た. 点数は高いほど性機能が良く, 点数が低いと性機 能が悪いことを示している．今回性機能を評価する上 で, 性欲は視覚によるものと接触によるものの 2 項目 の合計点を, 勃起は陰茎硬度と勃起持続時間の 2 項目 の合計点を採用した。

図 2 は性機能質問紙を健康男性 6,426 例に施行し,性 欲および勃起得点の累積度数分布の年齢推移をみたも のである．度数分布を基に点数の低い方から $10 \%$, $25 \%, 50 \%$ (中央值)， $75 \% ， 90 \%$ のが含まれるライ ンで示してある．このように健康男性であってもライ ンは加齢とともに右肩下がりとなっており, 高齢者で は若年者と同等に性機能を扱えないことがわかる.さ らに下方 $10 \%$ の領域に分布するものの割合が $10 \%$ 以上 
図 2 健康男性 6,426 例における性機能得点の累積度数分布図

性欲

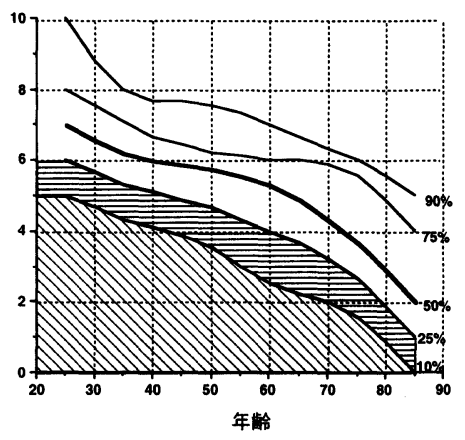

: 下方 $25 \%-10 \%$ 領域
勃起

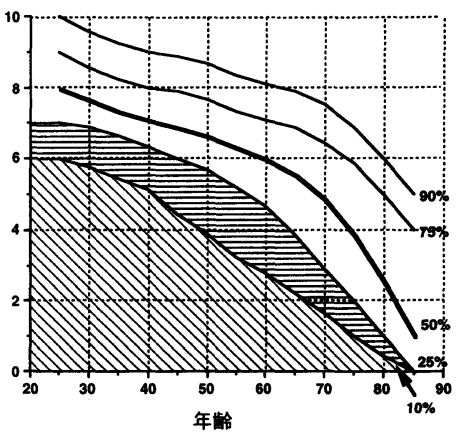

MIV: 下方 $10 \%$ 領域
表 1 勃起得点に奇与する因子とカテゴリー分類

\begin{tabular}{|c|c|c|c|c|}
\hline \multirow[b]{2}{*}{ 因子 } & \multicolumn{4}{|c|}{ カテコリー分䅡 } \\
\hline & 1点 & 2点 & | 3点 & 4点 \\
\hline 1.年粠 & \multicolumn{4}{|c|}{ 实教值 } \\
\hline 2.霍病胘问 & \multicolumn{4}{|c|}{ 实数僬 } \\
\hline $\begin{array}{l}\text { 3.四肢の=ューロ } \\
\text { の有無 }\end{array}$ & なし & कり & & \\
\hline 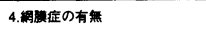 & なし & あり & & \\
\hline 5.サ菓上ストレス & 存し & あり & & \\
\hline 6.家莛内ストレス & 左し & あり & & \\
\hline 7.高血圧应の有無 & なし & कり & & \\
\hline 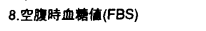 & 100未澫 & $100-200$ & $200-300$ & $300 \mathrm{k} 2 \mathrm{~L}$ \\
\hline 9.^モクロロビンA1侐 & 9未渾 & $9-15$ & 15-20 & 20以上 \\
\hline $\begin{array}{c}\text { 10.コントロールのための繹口乗 } \\
\text { またはインスリンの必要性 } \\
\end{array}$ & 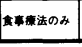 & 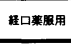 & அンスリン必国 & \\
\hline
\end{tabular}

存在すれば，同年代の健康男性と比べ性機能の低下例 が多いと判断した。

2）多変量解析による性機能の検討

糖尿病の勃起に影響を与えることが予想される因子 を表 1 に示した。そしてこれらの因子が勃起の状態を どのくらい説明し得るかを検討するため重回㷌分析に よる多変量解析を施行した．基準変数として質問紙の 勃起の得点をもちいた。説明変数としては, 表 1 に示 したように年齢，罹病期間，四肢のニューロパチーの 有無, 網膜症の有無, 仕事上や家庭内のストレスの有 無, 高血圧症の有無, 空腹時血糖值, へモグロビン A1 值，治療として経口薬やインスリンが必要かなどの 10 因子を検討し，それぞれの因子は内容に即したカテゴ リー分類を行い変数としてもちいた。

図 3 糖尿病症例における性欲の得点推移

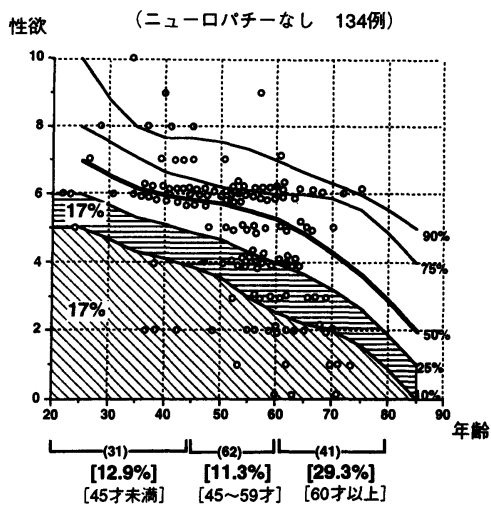

:方 $25 \%-10 \%$ 镇城

性欲 (ニューロパチーあり 67(例)

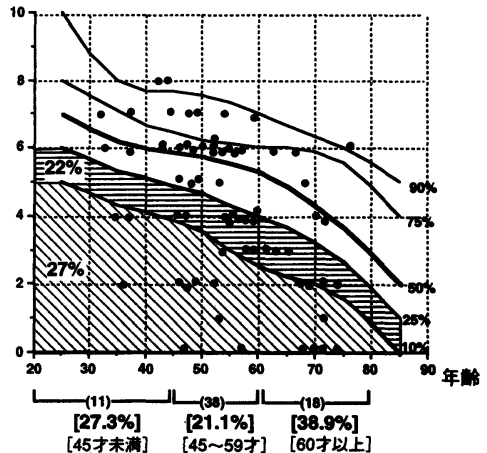

( )内, 症例数

[ ]内、下方 $10 \%$ 领域に存在する割合 
結果

1）性欲について

図 3 は糖尿病症例における性欲得点（視覚による性 欲と接触による性欲の合計点）の年齢推移をプロット したものである.ニューロパチーのないものにおいて， 60歳未満の症例では健康男性とほほ同様であるが，60 歳以上の高齢群で下方 $10 \%$ 領域に入ってくるものの割 合が $29.3 \%$ と多くなっている.ニューロパチーがある と, 高紫でないものにおいても性欲得点が下方 $10 \%$ 領 域に入ってくるものの割合が多くなっており，全年齢 を通して約 3 割の症例が下方 $10 \%$ 領域に存在した。
ニューロパチーは何らかの機序で性欲低下に影響をお よほしているようである。

2）勃起について

図 4 は糖尿病症例における勃起得点（陰茎硬度と勃 起持続時間の合計点）の年齢推移をプロットしたもの である.ニューロパチーのないものにおいて，60歳未 満の症例では健康男性とほほ同様であるが，60歳以上 の高齢群で下方 $10 \%$ 領域に入ってくるものの割合が $31.7 \%$ とかなり多くなることがわかる.ニューロパ チーのあるものにおいては, 勃起得点の低下を示す割 合は，45歳未満で18.2\%，45～59歳で44.7\%，60歳以

図 4 糖尿病症例における勃起の得点推移
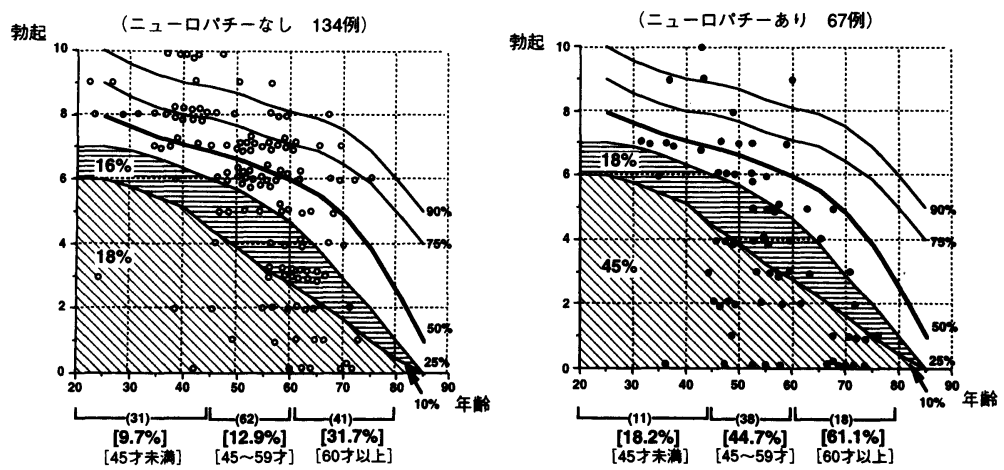

( )内, 症例数

[ ]内，下方10\%鎮域に存在する割合

図 5 陰茥硬度と勃起持続時間の関係

（健康男性5524例）

勃起持䋛時問

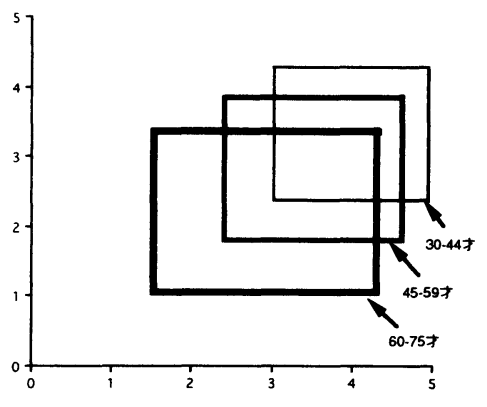

㓌茎硬度

$$
\text { （ニューロパチーなし 134例） }
$$

\section{勃起持緢時问}

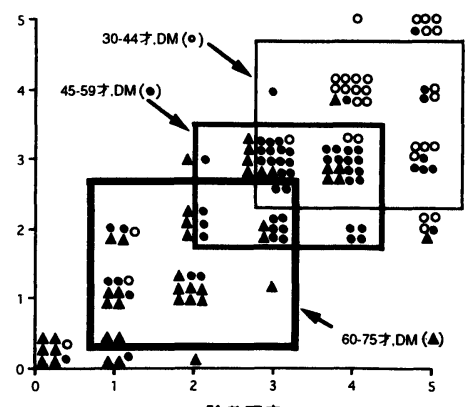

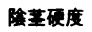

(ニューロパチーあり 67例）

\section{勃起持㧼時问}

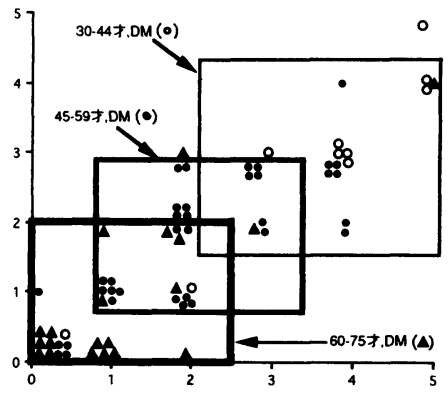

隆蕫硕度

- 30-44才,DM

- 45-59才,DM

: 得点のM-SD-M+SDで囲まれた領域を表す

$\Delta$ 60-75才,DM 
降で $61.1 \%$ の症例が下方 $10 \%$ 領域に存在しており， ニューロパチーのないものと比較すると早期かつ低下 度も著しいことがわかる．全年齢を通して下方 $10 \% の$ 領域に存在するものは，ニューロパチーのないもので 18\%,ニューロパチーのあるもので $45 \%$ となっていた。

以上の所見から糖尿病症例では健康男性に比し，60 歳を過ぎるころより勃起能低下出現が高率となり，一 方ニューロパチーのあることによって勃起能低下がよ り早期かつ顕著であることがわかる.

ただ勃起能と一口にいっても「陰茎硬度」と「勃起 持続時間」の因子があるので，その両因子がどのよう に変化するかを詳細に分析したのが図 5 である．両因 子をそれぞれの座標にとり，その分布が加齢によって どのように変化するか分析してみた．図中には各年齢
群での得点の $\mathrm{M}-\mathrm{SD} \sim \mathrm{M}+\mathrm{SD}$ の領域を四角で囲っ た。健康男性における両得点の加齢による低下パター ンは, 陰茎硬度および勃起持続時間とも同程度に徐々 に下降するという所見になっている。糖尿病において は陰茎硬度と勃起持続時間の低下度は健康男性に比し きわめて著しいが，両因子の低下はやはり健康男性と 同様に同程度の低下を示しており，どちらかがより極 端に低下するような例は存在しなかった。

これは糖尿病の勃起低下の内容が陰茎硬度低下や持 続時間低下のどちらかに偏るという特殊なものではな く, 健康人の加齢による勃起能低下同様, 両者が並行 して下降することがわかる．ただその下降度が同年齢 健康人より著しく高度であることが示されている. 60 歳以下（図 5 の○および○印）では糖尿病症例でも両

図 6 各年代における早朝勃起

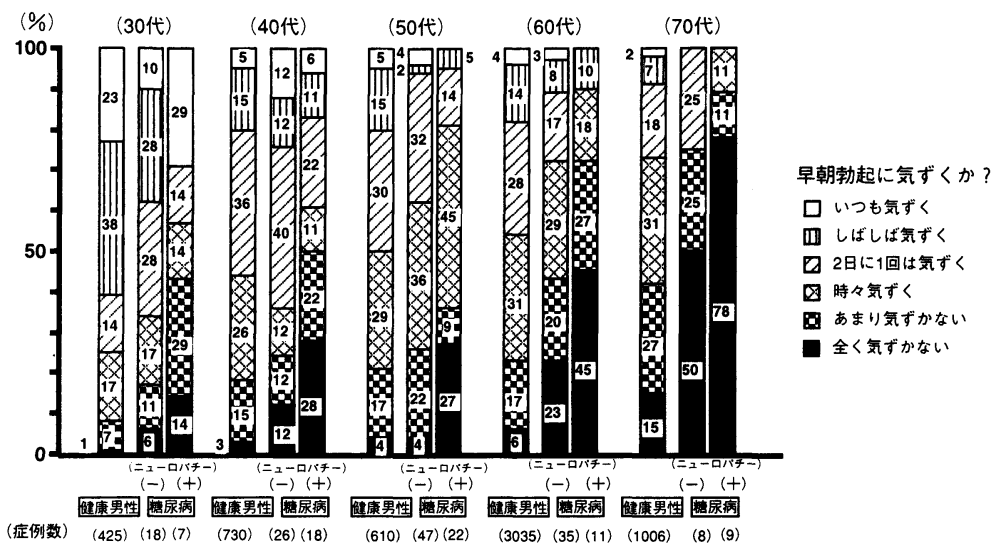

図 7 性欲と勃起の得点分布

（健康男性5524例）

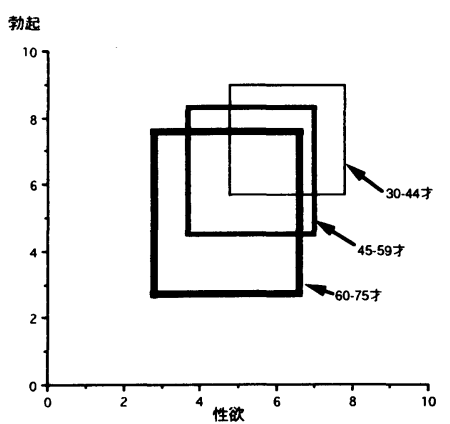

○ 30-44才,DM

- 45-59才,DM

$\triangle$ 60-75才,DM
（ニューロパチーなし 134例）
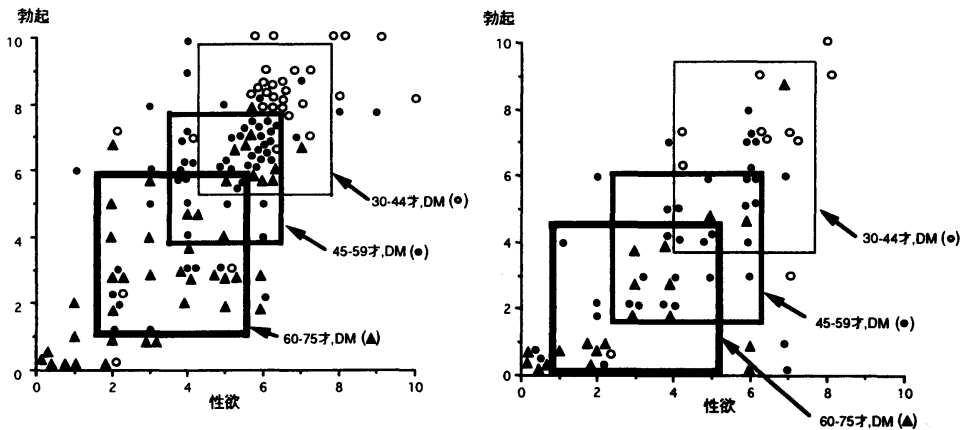
機能は健康男性とほほ同程度の得点を保っている症例 が多いが，60歳以降の高齢群（図 5 のム印）になると 加齢により低下が加速され，ことにニューロパチーを 有するものでは低下が早期かつ低下度も著しく, 図 4 でみられた所見と同様である。

図 6 に示すごとく, 早朝勃起は生理的勃起機能を知 る上である程度の目安となりうる.「早朝勃起に全く気 付かない人」は健康男性においては意外と少なく, 70 歳代においても15\%程度であった。一方, 糖尿病では まずニューロパチーを有するものが比較的早期に早朝 勃起に気付かなくなり，ニューロパチーのないものも 60 歳代では $1 / 4$ が, 70 歳代では半数が早朝勃起に気付か なくなっていた。さらにニューロパチーを有している
とその変化は一層著しいものとなっていた.

3）性欲と勃起の関係について

性欲得点と勃起得点との関連性に年齢がどのように 関与しているかを知るため, 図 7 に性欲得点と勃起得 点を両座標にとり，その分布が加齢によってどのよう に変化するか分析してみた。健康男性においては，45 歳未満, 45〜 59歳, 60 歳以上の群と, 加齢とともに性 欲と勃起が同時に，連続的に低下している。一方，糖 㽷病も同様に加齢とともに低下して行くが，その低下 の早さはかなり高度である。ことにニューロパチーの あるものにおいて顕著である。しかしニューロパチー のないものにおいても, 特に60歳以降の高齢群では健 康男性よりも低下がかなり加速されたものとなってい

図 8 各年代における性交頻度

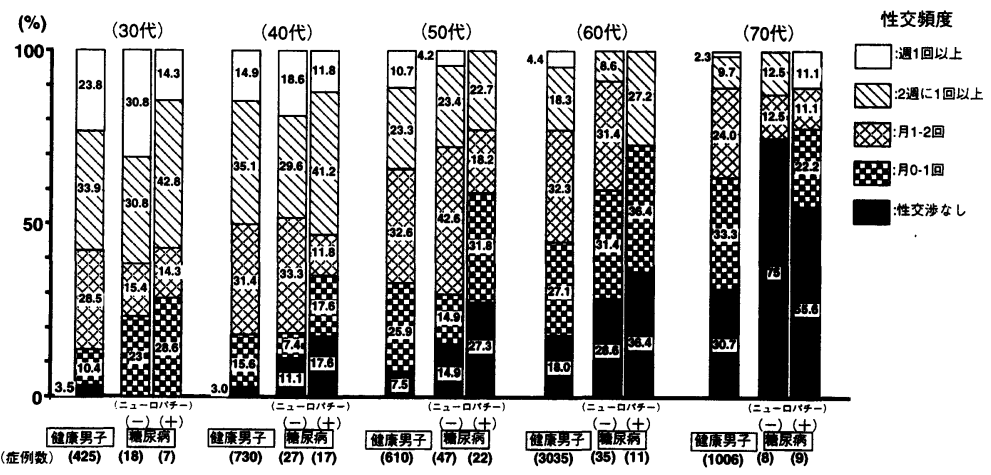

図 9 完全勃起障害例の年齢別頻度

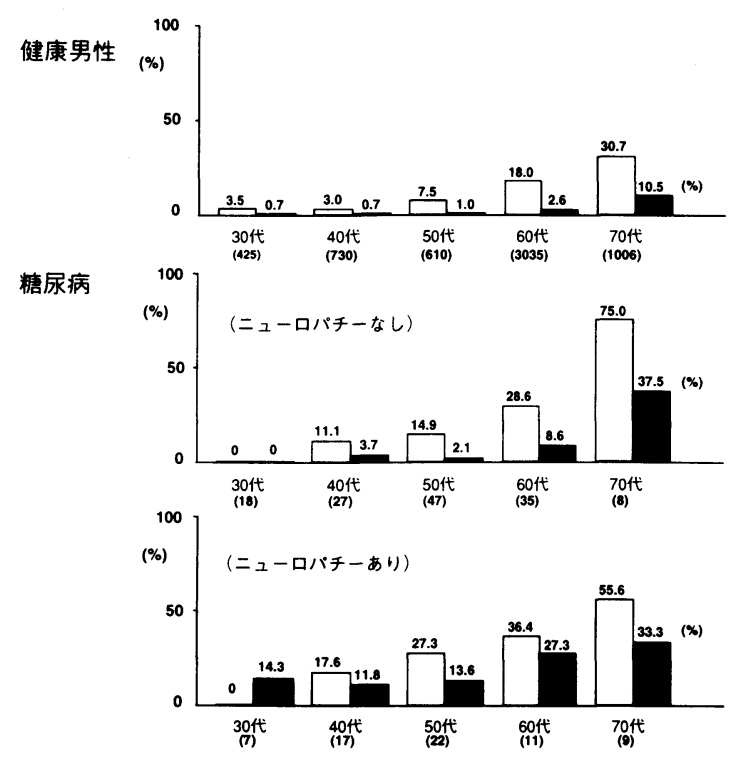


ることは注目すべき所見である。すなわち，糖尿病で の加齢による勃起能の低下は, 健康男性にみられる加 齢による変化や，またニューロパチーの存在だけでも 説明できず，糖尿病において加齢により促進される勃 起能低下因子が存在することが強く示唆されている.

4）性交頻度について

糖尿病症例の性交頻度を健康成人のそれと比較して 示すと図 8 のごとくになる.「全く性交涉なし」の例を みると，健康男性では 50 代までは 1 割未満であり， 60 歳以降その頻度が徐々に増加している。一方，糖尿病 症例では加齢による影響を考慮しても，全く性交涉を 有さないものの割合が大きくなっていた。ことに ニューロパチーを有する例では，「月 1 回未満」の例も 含めると 30 代で $28.6 \%, 40$ 代で $35.2 \%, 50$ 代で $59.1 \%$, 60 代で $72.8 \% ， 70$ 代では $77.8 \%$ と比較的早期より，さ らに年代がすすむごとに性的活動の低下する割合が増 加していた（図 8).

5）完全勃起障害例の年齢別頻度

図 4 に示したように，健康男性と比較することによ り, 糖尿病症例では勃起能の低下を示す例が多数存在 することがすでに判明したが，これをもって勃起障害 の頻度を特定することはできない.そこで「陰茎が全 く硬くならないもの」を「完全勃起障害例」とし，こ れを絶対的な勃起障害とすれば，その頻度は図 9 に示 したように，健康男性と同様に糖尿病症例でも加齢と ともに多くなり，ことにニューロパチーのあるもので は早期より完全勃起障害例の頻度が多くなっていた。

6）多変量解析による勃起障害の検討

さて，そのように糖尿病症例で性機能低下が著しい ことが明らかになったが，表 1 で示した性機能に影響 を与えると考えられる10因子がどのように勃起得点に 関与するかを単相関行列で検討した (表 2 )。図にみら

表 2 勃起得点に寄与するものとおもわれる因子の単 相関行列

\begin{tabular}{|c|c|c|c|c|c|c|c|c|c|c|c|}
\hline & 年的 & 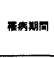 & 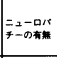 & 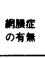 & $\begin{array}{l}\text { 保上 } \\
\text { ストレ }\end{array}$ & $\begin{array}{l}\text { 英應内 } \\
\text { ストレス }\end{array}$ & 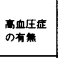 & 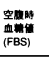 & 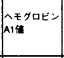 & 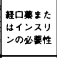 & 船 \\
\hline 年业 & 1.000 & 0.246 & 0.026 & 0.063 & 0.188 & 0.030 & 0.218 & -0.208 & -0.200 & -0.172 & -0.530 \\
\hline 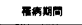 & & 1.000 & 0.265 & 0.263 & 0.119 & 0.043 & 0.119 & -0.018 & 0.114 & 0.310 & -0.335 \\
\hline 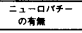 & & & 1.000 & 0.337 & 0.002 & 0.070 & 0.033 & 0.192 & 0.132 & 0.342 & -0.289 \\
\hline 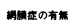 & & & & 1.000 & 0.193 & 0.056 & 0.144 & 0.021 & 0.068 & 0.328 & -0.217 \\
\hline 甘該上ストレス & & & & & 1.000 & 0.170 & 0.125 & -0.055 & 0.008 & 0.047 & -0.074 \\
\hline 䒠䃌内ストレス & & & & & & 1.000 & -0.010 & -0.006 & 0.070 & 0.144 & 0.015 \\
\hline 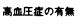 & & & & & & & 1.000 & -0.098 & -0.151 & -0.080 & -0.104 \\
\hline 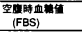 & & & & & & & & 1.000 & 0.334 & 0.213 & 0.035 \\
\hline ヘモタロビンAル & & & & & & & & & 1.000 & 0.409 & -0.023 \\
\hline 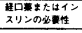 & & & & & & & & & & 1.000 & -0.161 \\
\hline 蛙 & & & & & & & & & & & 1.000 \\
\hline
\end{tabular}

図10 重回帰分析より得られた成績

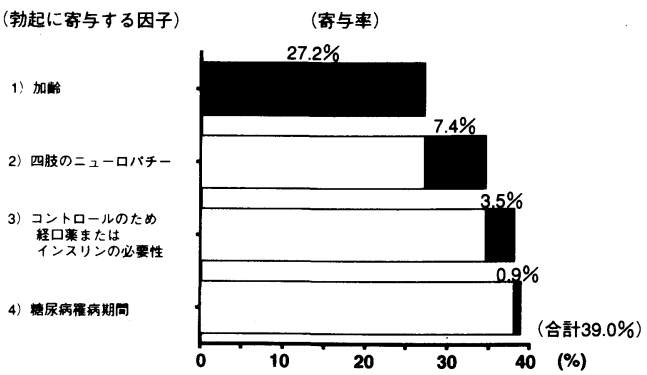

れるごとく, 勃起能との相関が比較的高い因子は, 年 齢, 罹病期間, ニューロパチーの有無, 網膜症の有無 などがあげられる。しかしながらこれら因子は相互に 複雑に関連しながら勃起能を規定していると考えられ る.そこで重回帰分析による多変量解析を用いて，こ れら因子の勃起能に対する寄与度の検討した。

その成績を図10に示したが，勃起に寄与する因子と して第一に加齢（寄与率 $27.2 \%$ )，続いてニューロパ チー (寄与率 $7.4 \%$ ) が挙げられ，この 2 つの因子が糖 尿病の勃起障害の説明因子として約 $1 / 3$ を占めること が示されている.さらにインスリンの必要性や罹病期 間も糖尿病の勃起障害の説明因子としての意義をもつ ことがわかる。

この分析所見に, 糖尿病の勃起低下に一番大きく寄 与している因子が「加齢」であったことは興味深い所 見である。これは先にも述べたように，糖尿病におい ては加齢により促進される強力な勃起障害因子が存在 することが示唆されている。

\section{考案}

男性性機能を理解するうえで, 性欲, 勃起能および 性的活動の指標となる性交頻度を詳細に分析する必要 がある.しかし, 問題なのはこれら性機能が健康男性 においても加齢により徐々に低下することを考慮しつ つ, 糖尿病症例の性機能低下を論じなければならない ことである．ところが従来の糖尿病患者の性機能の検 討では, 健康男性と比較しつつ加齢による変化を検討 したものは非常に少ない(3)4. そこで，我々はかねてよ り札幌医大式性機能質問紙を作製し，それを用いての 健康成人男性の加齢による性機能低下の頻度を調査 し，報告してきている ${ }^{2}$. そこで今回，その質問紙を用 いて糖尿病201例において性機能を調査し, 健康成人男 性との比較において糖尿病の性機能の検討を行ったわ けである。それにより，健康男性における加齢による 
性機能低下という影響因子を除きつつ，糖尿病症例の 性機能低下を論ずることが可能になった。質問紙での 調査は性欲，勃起能，および性交頻度の 3 点に焦点を 合わせ検討を行った.

まず，「性欲」については今までの報告では意見が分 かれており, Kolodney ら ${ }^{5}$ は糖尿病175例の検討で性 欲低下はないとしているが, 一方, 高橋ら ${ }^{6}$ は200例の 検討で年㱓に関係なく勃起障害患者の約 8 割に，また 勃起障害がなくても正常人よりは性欲の低下を認めた としている.

今回の検討では, 60 歳未満においては糖尿病症例で の性欲低下は比較的軽度であるが，60歳以上の高齢者 になるとことにニューロパチーを有しているものは 健康男性に比べ性欲低下が著しい。 また，健康男性と 比較した今回の成績によると，性欲と勃起の低下のし かたは健康男性の加齢による低下と同様に両者が低下 していた．そしてその低下の速度は健康男性の加齢に よる変化を上回るものであった．糖尿病では加齢や ニューロパチーによって, 性欲に関する中枢神経系に 対しても，通常の加齢現象を加速させていることも考 えられた. Nofzinger ら゙は糖尿病性インポテンスの 勃起障害の原因として, 末梢神経障害のみならず中枢 神経障害の関与もあるとしており, 性欲低下のメカニ ズムにもその中枢性障害の関与があるのかも知れな い.

一方, 白井 ${ }^{8)}$ にると, 糖尿病性インポテンスの場 合, CMI やMAS など心理検査でノイローゼ傾向や不 安傾向あるいはうつ傾向を示す症例がかなりみられた としており, 性欲が低下しても不思議ではない心理状 態の患者が多く存在することも事実であろう.

「勃起」についての従来の報告には糖尿病䍜病期間 の長いものやインスリン治療者が勃起障害のある群に 多いという報告 ${ }^{699)}$ があるが，一方有意な差がないとの 報告5)もり，意見の一致をみない. 本成績でも罹病期 間の長いものやインスリン治療者と勃起得点の低下に ある程度の関連はあったが，あまり大きな因子とはな らなかった。むしろ糖尿病症例における勃起障害は60 歳を過ぎる頃より，ことにニューロパチーを有するも のではさらに早期に著明となり，加齢やニューロパ チーによる影響が大きいことが今回の検討で判明し た。

一方，「勃起障害」において心理的因子を考慮するこ とは重要である. しかし糖尿病性勃起障害例について はあまり心理的な関心は払われていない。これは糖尿
病性勃起障害が一般的に器質的なものと昔からいわれ てきたことによるものだろう。しかし糖尿病のような 慢性疾患では, 疾患そのものに対する不安や生活上の ストレスがさらに性機能障害を複雑にしていることは 想像に難くない。事実, Buvat $ら^{10)}$ は糖尿病のインポ テンス症例ではそうでないものより MMPI で多く異

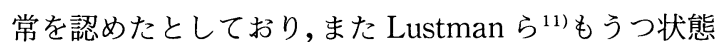
や不安状態が勃起障害と深く関係しているとのべてい る.このように糖尿病患者の勃起低下の主因は血管や 神経など器質的障害であるにしても, 心因性の要因も 無視できないことを忘れてはいけない.

糖尿病におけるインポテンスの頻度がどの程度発症 しているかを検討した報告は少なくないが1)，その報 告されている数值は $28 \%$ ～75\%とかなりのバラツキが ある. その理由の一つとして，加齢による性機能への 影響が大きいにもかかわらず，年齢を考慮して頻度を 論じていないことがあろう。さらにインポテンスの定 義の違いもあると思われる. 先にも述べたように我々 の検討では, 勃起力が低下している例は健康男性と比 較しても多数存在するが, 陰茎が全く硬くならない「完 全勃起障害例」でみると，その頻度は70歳までは 3 割 以内, ニューロパチーを有さない例では $10 \%$ 以内と意 外に少ないことになる.さらに勃起障害の頻度は年齢 によって差があり，年齢の因子を無視して頻度を論じ ることには問題があると思われる。

「性交頻度」は全性機能の総合としての性的活動の 指標となるものである.上述のように性欲, 勃起能が それぞれ加齢やニューロパチーによって著しく低下し ていることからも推定されるように，性交頻度も糖尿 病では性的活動が健康男性に比して加齢によって著し く低下してゆきことにニューロパチーを有する群で それが著しいことがわかる。

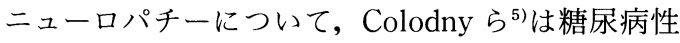
インポテンスの $37.5 \%$ (85例中 32 例)に臨床的なニュー ロパチーを認めたとしている.Quadri ら ${ }^{12)} も$ 自律神経 機能検査としての心血管系反射テストをおこない, 糖 尿病における性機能障害の大きな原因は副交感神経系 のニューロパチーであるとした。また Ellenberg ${ }^{13)} も$ 糖尿病インポテンスでは神経因性膀胱などの自律神経 障害を合併することが多いとしている. 我々も勃起に 関した神経障害の一つの指標となる球海綿体反射伝導 時間, および陰茎背神経伝導速度を糖尿病性勃起障害 例に測定したところ，それぞれ $27 \% ， 53.3 \%$ に異常を 認めている ${ }^{14)}$. 
一方，血管障害も糖尿病における性機能障害の大き な要因と考えられている．網膜症は血管障害の一つの 指標になるが，McCulloch ら ${ }^{9)}$ はインポテンス群に明 らかに網膜症が多いとしている．しかしながら今回の 多変量解析では網膜症は大きな因子にはならなかっ た。むしろ加齢が大きく勃起に寄与していた．結果に も述べたように，糖尿病での勃起の低下は健康男性に おきるとされる加齢による変化だけでは説明できず, またニューロパチーだけによっても説明できず，何か 別な因子が影響していると考えられる.糖尿病の場合, 一体加齢の裏に何があるのか.

Hirshkowitz $~^{\left.{ }^{15}\right)}$ は糖尿病症例の夜間睡眠時勃起現 象（NPT）を，年齢を考慮しつつ，糖尿病を有さない 症例と比較すると, 糖尿病症例では加齢に相当すると される NPT の減弱がより早期におきていたとしてい る.さらに Jevtich ら ${ }^{16)}$ は Doppler 法をもちい直接陰 茎動脈の血流を調べ，糖尿病性勃起障害例（47例）の 約 7 割に異常を認めたとしている。このように糖尿病 では網膜症のような microangiopathy だけでなく, 陰 茎動脈におきると想定される macroangiopathy の存 在も決して無視できないことがわかる.

以上より，健康男性では加齢により増加する勃起障 害の原因として, 陰茎血管系障害が重要である ${ }^{17)}$ が, 糖 尿病においては加齢によって, 健康男性におけるより もさらに加速された血管障害があり，それが今回加齢 という因子に代表されたことが推測される。

本研究を行うにあたり，多大なる御協力と御助言をいた だいた, 札幌医科大学第 1 内科鬼原 彰先生, 同交会病院内 科細川英明先生, 恵仁会佐々木内科病院佐々木 嵩先生, 栗 沢町立病院内科牧田善二先生, 旭川赤十字病院内科岩島保 法先生, 佐藤孝生先生, 小澊北生病院内科数内信治先生, 苫 小牧市立病院内科熊野博之先生, 浦河赤十字病院内科西田 聖先生, 市立釧路病院内科種田紳二先生, 函館五稜郭病院内 科角本芳隆先生（順不同）に深謝致します。

\section{文献}

1) Zemel, P: Sexual dysfunction in diabetic patient with hypertension. Am. J. Cardiol., 61, 27-33, 1988.

2）熊本悦明：加齢による男子性機能低下. 日老医誌, 29, 350-360, 1992.

3) S $\phi$ ren, B.J.: Diabetic sexual dysfunction: A comparative study of 160 insulin treated diabetic men and women and age-matched control group. Arch. Sexual Behavior, 10, 493-504, 1981.

4) Thomas, M., Sheldon, M.R., Vernon,M.C. and
Cynthia, B.B.: The role of aging and chronic disease in sexual dysfunction. J.A.G.S., 36, 520-524, 1988.

5) Kolodney, R.C., Kahn, C.B., Goldstein, H.H. and Barnett, D.M. : Sexual dysfunction in diabetic men. Diabetes, 23, 306-309, 1973.

6）高橋良当, 井上幸子, 平田幸正：糖尿病性インポテ ンス症例の臨床像一非インポテンス群との比較検 討一。糖尿病, 28，53-59，1985.

7) Nofzinger, E.A. and Schmidt, H.S.: An exploration of central dysregulation of erectile function as a contributing cause of diabetic impotence. J. Nerv. Ment. Dis., 178, 90-95, 1990.

8）白井将文：糖尿病における性機能。ホルモンと臨 床, 33, 45-50, 1985 .

9) McCulloch, D.K., Campbell, I.W., Wu,F.C., Prescott, R.C. and Clarke, B.F. : The prevalence of diabetic impotence. Diabetologia 18, 279-281, 1980.

10) Buvat, J., Lemaire, A., Herbaut, M.B., Guieu, J. D., Bailleul, J.P. and Fossati, P.: Comparative investigations in 26 impotent and 26 nonimpotent diabetic patients. J. Urol., 133, 34-38, 1985.

11) Lustman, P.J. and Clouse, R.E.: Relationship of psychiatric illness to impotence in men with diabetes. Diabetes Care. 13, 893-895, 1990.

12) Quadri, R., Veglio, M., Flecchia, D., Tonda, L., DeLorenzo,F., Chiandussi, L. and Fonzo, D.: Autonomic neuropathy and sexual impotence in diabetic patients: Analysis of cardiovascular reflexes. Andrologia, 21, 346-352, 1989.

13) Ellenberg, $M:$ Impotence in diabetes: The neurologic factor. Ann. Intern. Med., 75, 213-219, 1971.

14）山口康宏, 熊本悦明, 青木正治, 佐藤嘉一, 毛利和 富, 鬼原 彰, 谷内 昭, 後藤義朗, 漆崎一朗, 婁 内信治, 長井靖仁, 細井英明 : 糖尿病性インポテン スに扔引陰茎背神経伝導速度測定の臨床的意 義. 糖尿病, 31，401-406, 1988.

15) Hirshkowitz, M., Karacan, I., Rando,K.C., Williams, R.L. and Howell, J.W.: Diabetes, erectile dysfunction, and sleep-related erections. Sleep, 13, 53-68, 1990.

16) Jevtich, M.J., Edson,M., Jarman, W.D. and Herrera, H.H.: Vascular factor in erectile failure among diabetics. Urology, 19, 163-168, 1982.

17）青木正治, 熊本悦明：加齢による勃起能低下の背 景因子の分析. 日泌尿会誌, 81, 1633-1641, 1990. (1994年2月15日受付，6月16日受理，特別掲載） 